* Mestrando no programa de Pós-Graduação Stricto Sensu em Direitos e Garantias Fundamentais da FDV/ ES. Especialista em Direito Empresarial pela Fundação Getúlio Vargas -FGV- (2014). Especialista em Direito Público e Tributário pela Universidade Cândido Mendes (2007). Graduado em Direito pela Universidade Cândido Mendes (2003).

jbguedes8@yahoo.com.br

** Possui graduação em Direito pelo Centro Superior de Ciências Sociais de Vila Velha (1988), graduação em Ciências Sociais pela Universidade Federal do Espírito Santo (1994), mestrado em Direito pela Universidade Federal de Minas Gerais (1998) e doutorado em Direito pela Universidade Federal de Minas Gerais (2001). Advogado - Fabriz, Ulhoa \& Advogados Associados, presidente da Academia Brasileira de Direitos Humanos, professor doutor nível I da Faculdade de Direito de Vitória e professor associado III da Universidade Federal do Espírito Santo. daury@terra.com.br

\section{Dever Fundamental de CoOperação \\ em Processos Administrativos da Autoridade Marítima: Possibilidade de Aplicação Subsidiária do CPC no Que TANGE À MÁ-FÉ 1}

\author{
The Fundamental Duty of Cooperation \\ in Maritime Legal Procedures Possible \\ Subsidiary ApPlicATION OF THE BRAZILIAN \\ Civil Procedure Code Regarding Bad \\ FAITH
}

\section{João Bernardo Antunes de Azevedo Guedes* Daury Cesar Fabriz**}

Como citar: GUEDES, João Bernardo Antunes de Azevedo. FABRIZ, Daury Cesar. Dever fundamental de cooperação em processo administrativo da autoridade marítima: possibilidade de aplicação subsidiária do CPC no eu tange à má-fé. Revista do Direito Público, Londrina, v. 12, n. 3, p.115-152, dez. 2017. DOI: $10.5433 / 1980-511 \mathrm{X} 2017 \mathrm{v} 12 \mathrm{n} 3 \mathrm{p} 115$. ISSN: $1980-511 X$.

Resumo: O presente artigo propõe analisar a necessidade de atuação conforme a boa-fé objetiva e a observância de um dever fundamental de cooperação, condutas constantes dos artigos

1 Pesquisa desenvolvida no Grupo de Pesquisa "Estado, Democracia Constitucional e Direitos Fundamentais" do Programa de Pós Graduação Stricto Sensu em Direitos e Garantias Fundamentais da Faculdade de Direito de Vitória - FDV. 
$5^{\circ}$ e $6^{\circ}$ do Código de Processo Civil (CPC) pelo administrado. A base normativa para tal fim é o artigo 15 do mesmo diploma, uma vez que a Lei n. ${ }^{0}$ 9.537/97, que dispõe sobre a Segurança do Tráfego Aquaviário (LESTA); o Decreto n. ${ }^{\circ}$ 2.598 de 1998 (RLESTA) que o regulamenta; a NORMAM 07 (norma infra-legal da autoridade marítima) são silentes quanto a este aspecto, possibilitando que o CPC seja subsidiariamente aplicado. A análise versará sobre os processos nos quais a administração se vê diante de uma quebra desse dever fundamental pelo excesso no direito de defesa (petição) exercido pela parte. Nesses casos, não há contestação quanto à imputabilidade de autoria e materialidade - implicitamente a parte acaba por admitir o cometimento da infração - e apenas constam das peças e recursos, argumentos inócuos, sem técnica e nitidamente protelatórios. Este fenômeno revela-se como uma prática astuciosa e caminha em sentido diametralmente oposto ao que se entende por boa-fé objetiva. Há uma dilação estendida no trâmite nesses processos que compromete o bom andamento e a eficiência da máquina pública. Quebra-se aqui, ainda, o dever de solidariedade, já que haverá reflexos em outros cidadãos que deixam de ter suas causas julgadas em tempo hábil, e assim uma garantia a um direito fundamental à duração razoável do processo começa a se esvair. Dessa forma, constatando-se um excesso no direito de petição que seja marcado por uma das condutas de má-fé elencadas no artigo 80 do CPC 
nos autos do processo administrativo, pode a autoridade marítima aplicar uma sanção a este título ao administrado. Assim, existirá o dever de reparação a título de perdas e danos, fato este que pode auxiliar a por a fim ou ao menos inibir essa prática protelatória que compromete a boa administração do Estado.

Palavras-chave: Infração às normas de segurança do tráfego aquaviário. Dever fundamental de cooperação. Código de Processo Civil.

Abstract: This research explores an individual's necessity to act according to good faith and with respect to the fundamental responsibility of cooperation, as seen in articles 5 and 6 of the Brazilian Civil Procedural Code (CPC), respectively. Furthermore, article 15 structures its normative base; Law n. 9.537 regulates maritime traffic rules; and Decree n. 2.598 and NORMAM 07 does not address this theme. Nevertheless, this paper questions the possible subsidiary application of the CPC. Sequentially, this study examines the process in which maritime authority notices violations of the fundamental duty to cooperate in cases of misuse in statement of claims. In these cases, the challenges are inefficient in relation to questions relating to a part's material responsibility; consequentially, they can only use innocuous and procrastinating arguments. In light of this phenomenon, the principle of good faith is not 
upheld, as it causes delays in administrative processes and reduces the efficiency of the administration. Additionally, these acts break the duty of solidarity, in such a way that other citizens are affected, as they do not have their cases judged in reasonable time. Thus, by extrapolating the use of the right to petition, which conducts are listed on Article 80 of CPC in relation to the administrative process, the maritime authority can impose penalties to the plaintiff. As a result, actions like these stated gives rise to the duty to repair damages and legal responsibility can reduce actions that embarrass the administration of the State.

Keywords: Violation of marine traffic rules. Cooperation's Fundamental Duty. Civil Procedure Code. 


\section{INTRODUÇÃO}

A Marinha, o Exército e a Aeronáutica nos termos do artigo 142 da Constituição Federal constituem as Forças Armadas. As três instituições estão hoje subordinadas ao Ministério da Defesa, sendo o papel da Defesa Nacional proteger os interesses nacionais, os cidadãos, os bens e os recursos brasileiros.

Nos termos do artigo 17 da Lei Complementar n. ${ }^{\circ} 97$ de 1999 que dispõe sobre as normas gerais para a organização, o emprego e o preparo das Forças Armadas, fica estabelecido que cabe à Marinha orientar e controlar a Marinha Mercante e suas atividades correlatas, no que interessa à defesa nacional; prover a segurança da navegação aquaviária; contribuir para a formulação e condução de políticas nacionais que digam respeito ao mar; e implementar e fiscalizar o cumprimento de leis e regulamentos, no mar e nas águas interiores, em coordenação com outros órgãos do Poder Executivo, federal ou estadual, quando se fizer necessária, em razão de competências específicas (BRASIL, 1999a).

A Lei n. ${ }^{\circ}$ 9.537/97, que dispõe sobre a Segurança do Tráfego Aquaviário (a partir deste momento denominada "LESTA"), (BRASIL, 1997) por seu turno, preceitua que a autoridade marítima será exercida pelo Comando da Marinha e estatui algumas de suas competências: promover a sua implementação e execução; elaborar normas para tráfego e permanências de embarcações nas Águas Jurisdicionais Brasileiras (denominada, neste trabalho, daqui por diante de "AJB"); realizar inspeções navais e vistorias que, segundo Gilbertoni (2005) ficam a cargo das Capitanias dos Portos, que devem adotar medidas administrativas e penalidades consoante o cometimento de infrações; para fins de zelar pela segurança no mar e em hidrovias interiores. 
Assim, se por ocasião destas ações for constatada alguma irregularidade, o condutor da embarcação deverá ser orientado acerca da violação cometida e notificado para comparecimento na sede da autoridade marítima, quando então será iniciado um processo administrativo por infração às normas de segurança do tráfego aquaviário.

$\mathrm{O}$ aludido procedimento tramita em conformidade com o ordenamento jurídico pátrio e sempre se desenvolve através de uma leitura constitucional, respeitando os corolários da lei maior, como contraditório, ampla defesa, devido processo legal, duração razoável do processo, publicidade, moralidade, em suma, todos os preceitos legais garantidores da defesa em seu sentido mais amplo (impugnação, pedido de revogação de ato administrativo, pedido de reconsideração, recurso). São então facultadas todas as possibilidades de a parte apresentar peças de defesa e as mesmas são levadas à apreciação da autoridade competente, sem qualquer tipo de cerceamento, de modo a garantir aos cidadãos a concretização destes direitos. É possível afirmar, então, categoricamente, que a autoridade marítima respeita o direito de petição do cidadão constitucionalmente assegurado e fruto de muitas conquistas históricas. Do mesmo modo, ao decidir sobre os pleitos apresentados, sempre fundamenta seus atos administrativos.

$\mathrm{Na}$ esteira desse pensamento, encontra-se Nelson Nery Junior quando registra que:

[...] no processo administrativo igualmente incide o princípio do contraditório, os demais princípios constitucionais do processo (devido processo legal, duração razoável do processo, proibição da prova obtida ilicitamente, motivação, das decisões administrativas, duplo 
grau de jurisdição, ampla defesa, etc.), bem como todos os princípios fundamentais da administração pública (legalidade, moralidade administrativa, eficiência, impessoalidade, publicidade, segurança jurídica, confiança, boafé objetiva, proibição de venire contra factum proprium, proibição de atuação arbitrária, etc.) (NERY JUNIOR, 2012, p. 225-226).

Entretanto, há situações em que os infratores das normas do tráfego aquaviário cometem excessos no exercício deste direito de defesa (petição/recurso). As práticas que aqui serão analisadas referem-se aos casos de excessos e abusos constatados em petições de impugnação (defesa/recurso) originárias de imputação das mais variadas infrações e são assim considerados quando a defesa deixa de se ater às questões técnicas, aos preceitos legais, ao fato concreto e traz em seu corpo temas impertinentes e incabíveis para o propósito que servem. Em outras palavras, não há negativa do cometimento da infração, de eventual ilegalidade na imputação do ato, e sim alegações vagas, genéricas e carregadas de fatos que não guardam qualquer relação de causa-efeito da infração cometida.

Logo, tais peças revestem-se de um caráter protelatório e desidioso, onde a boa-fé objetiva sucumbe frente a artifícios pífios ${ }^{2} \mathrm{e}$

2 Para exemplificar: 1) Seria o caso de um pescador com mais de vinte anos de profissão e contato diuturno com o mar, vir a culpar a natureza - contato com o sol e com a água salgada - por seu barco não possuir estampado em seu costado o número de inscrição. Alega que o desgaste criou tal situação para ter sido notificado. Não há aqui negativa de cometimento da infração, e sim apresentação de argumento que beira a desídia. 2) O caso de um condutor de embarcação com excesso de lotação, que admite no momento da abordagem haver excesso de ocupantes, mas no seu entendimento por todos estarem portando coletes, não merecia qualquer punição. 3) Do mesmo modo, em outro caso com excesso de lotação, a parte não nega esta infração, mas tenta se esquivar de uma penalidade informando que seu barco estava fundeado. Ora, descabido argumento, pois o excesso ocorreu, a segurança da navegação foi posta em risco e eventual afundamento decorrente deste ato poderia ser fatal. 4) Também há situações de alegado "desconhecimento de proibição de determinadas manobras e ações", tais como navegar em local proibido, não portar documentos, etc. Estes argumentos também são corriqueiros, embora no ordenamento jurídico pátrio ninguém pode se 
acabam por significar excessos no exercício deste direito de defesa que lhes é assegurado. Compromete-se, aqui, a eficiência da administração pública.

Desta feita, o percurso a ser trilhado no presente trabalho será o seguinte: primeiramente serão apontados os traços gerais do processo administrativo por infrações às normas de segurança do tráfego aquaviário, ocasião em que serão trazidas a competência da autoridade marítima, apontados os principais traços: (i) da LESTA, (ii) do Decreto n. ${ }^{\circ} 2.596$ de 1998, que a regulamenta (denominada, neste trabalho, daqui por diante de "RLESTA") e (iii) a Norma da Autoridade Marítima 07 (a partir deste momento denominada neste trabalho de "NORMAM 07") e indicadas as etapas do processo em tela (BRASIL, 1998).

Em um segundo momento, será trazido à baila o direito de defesa (sob um viés amplo, recebido como direito de petição) e demonstrando que as peças recebidas a este título assim o são e tramitam por respeito ao direito de petição e com o fito de se garantir a plenitude da ampla defesa e do contraditório, a economicidade e instrumentalidade das formas (já que não são poucos os casos em que carecem de formalidade e técnica).

Posteriormente, serão trazidos os aspectos relativos à boa-fé objetiva e ao dever fundamental de cooperação à luz do CPC, incluindose as consequências de sua desobediência.

Ao final, serão demonstrados os aspectos que geram o excesso

escusar de cumprir a lei, alegando que não a conhece. 5) Em outra hipótese um condutor de embarcação clama por socorro, pois seu colega encontra-se embriagado e ambos estão à deriva. Assim, a autoridade marítima não poupa esforços, envia agentes ao local, utiliza seus meios navais para a faina e os socorre. O condutor por ocasião da sua peça de defesa no auto de infração alega que não estava conduzindo a embarcação e que não estava à deriva. 6) Por vezes o condutor não contesta a imputação do cometimento da infração solicitando "clemência" do julgador, quando essa possibilidade sequer consta das normas invocadas. Ou seja, diversos são os exemplos de processos em que o objeto propriamente dito não é impugnado, o foco da discussão se desvirtua totalmente e a autoridade marítima despende um tempo precioso sem a menor necessidade para tratar desta causa. Por óbvio isso tem consequência negativa para outras causas de outros particulares que não terão em seus processos a garantia de uma duração razoável. 
no exercício do direito de defesa (recurso - petição) e a possibilidade de rotulá-las como eivadas de má-fé, culminando com a aplicação das sanções previstas no CPC em sede deste processo administrativo ora estudado, ante a possibilidade de sua aplicação em caráter subsidiário.

\section{ASPECTOS GERAIS SOBRE O PROCESSO ADMINISTRATIVO DECORRENTE DE INFRAÇÃO DAS NORMAS DE SEGURANÇA DO TRÁFEGO AQUAVIÁRIO}

\subsection{A competência da marinha como autoridade marítima}

A Constituição Federal de 1988 (BRASIL, 1988) que representou um marco para a história deste país inovou e trouxe em seu texto um vasto rol de direitos fundamentais e, mais importante, prometeu garantir os mesmos. Ela, chamada de cidadã, por fazer constar de seu bojo diversos anseios do povo brasileiro, aborda uma gama de variados temas. Acerca dessa característica, cabe Fabriz observa que

[...] nas experiências constituintes brasileiras anteriores ressentiu-se a ausência popular no debate constituinte, o processo ocorrido na década de 80 mostrou-se particularmente rico e peculiar no que se refere à participação popular, estando ainda em vigência a ordem jurídica anterior, com as suas instituições em pleno funcionamento. (FABRIZ, 2008).

Entre eles, conforme já narrado, seu artigo 142 indica que as Forças Armadas são constituídas pela Marinha, pelo Exército e pela Aeronáutica, destinando-se à defesa da Pátria, à garantia dos poderes 
constitucionais e, por iniciativa de qualquer destes, da lei e da ordem. Reitera-se, ainda, que a Lei Complementar n. 97 de 1999 (BRASIL, 1999a), também traz atribuições da Marinha, dentre as quais a de prover a segurança da navegação aquaviária; e implementar e fiscalizar o cumprimento de leis e regulamentos, no mar e nas águas interiores. $\mathrm{O}$ mesmo diploma ainda reza que pela especificidade dessas atribuições, é da competência do Comandante da Marinha o trato dos assuntos supracitados, designando-lhe, ainda como "autoridade marítima", para esse fim. Logo, a Marinha deve zelar pelos mares e lagoas e prover a regulamentação do tráfego aquaviário. Agindo dessa forma, os recursos estarão seguros, assim como os homens do mar estarão protegidos (são estes que conduzem as embarcações), pelo que regulamentando o tráfego marítimo mais uma de suas funções estará cumprida, qual seja, a de proteger os cidadãos.

A LESTA prevê que o exercício da autoridade marítima ficará a cargo do Comando da Marinha' bem como elenca suas atribuições. Do mesmo modo, o RLESTA e a NORMAM 07 que são um Decreto e uma Norma infra-legal, foram criados em decorrência dos artigos 40 e $4^{\circ}$, I, "c", da LESTA, respectivamente, abordam essa matéria. Em síntese, ante a previsão nos diplomas acima narrados, mostra-se que é de competência do Comando da Marinha exercer as funções de autoridade marítima (BRASIL, 2003).

\subsection{Lesta, Rlesta e Normam 07: principais normas que regem a inspeção naval e a segurança do tráfego aquaviário}

São três as principais normas que regulamentam as ações de inspeção naval nas AJB: LESTA, RLESTA E NORMAM 07. Nesses 
diplomas constam as atribuições da autoridade marítima, sua competência, as hipóteses que em sendo concretizadas constituem infração ao tráfego aquaviário, bem como quais são as penalidades cabíveis para esses casos. Neste sentido, cabe de forma sintética assinalar pontos relevantes de cada um destes diplomas:

A LESTA rege a segurança da navegação e na sua parte inicial traz alguns conceitos e definições acerca de termos técnicos atinentes à marinharia e estabelece quais são as atribuições da autoridade marítima, entre as quais a de elaborar normas sobre realização de inspeções navais e vistorias (previsto no artigo 4", I, "c" e cumprida com a NORMAM 07); e de executar a inspeção naval e executar vistorias (artigo $4^{\circ}$, IX e X). Outrossim, traz definições e atribuições do pessoal de bordo e menciona em que consiste o serviço de praticagem.

A seguir em seu capítulo IV aponta as medidas administrativas que podem ser aplicadas pela da autoridade marítima (a título exemplificativo: apreensão do certificado de habilitação e apreensão, retirada do tráfego ou impedimento da saída de embarcação) quando da violação da norma.

Já em seu capítulo $\mathrm{V}$, o legislador foi taxativo em prescrever que "as penalidades serão aplicadas mediante procedimento administrativo, que se inicia com o auto de infração, assegurados o contraditório e a ampla defesa". Também ali são apontadas as fases do procedimento e de forma minuciosa, descritas as penalidades cabíveis (multa; suspensão do certificado de habilitação; cancelamento do certificado de habilitação; demolição de obras e benfeitorias), bem como são trazidas circunstâncias agravantes e atenuantes.

Por fim, no capítulo VI que traz as disposições finais transitórias, além do já narrado artigo 39 que estatui quem é a autoridade marítima, 
destaca-se o artigo 40 que preceitua que a LESTA seria regulamentada pelo Poder Executivo no prazo de cento e oitenta dias, contados a partir da sua publicação.

O RLESTA regulamenta a LESTA e em sua Seção I invoca o pessoal, traz as classificações de embarcações e ressalta como se constitui o serviço de praticagem. No Capítulo IV aborda as infrações e penalidades, indicando quem pode ser o autor material do fato e qual será o momento da constatação do seu cometimento.

Cabe aqui, ressaltar também, a previsão de que para efeitos de multa, a classificação é feita por grupos, sendo seus valores estabelecidos pelo Anexo II do próprio RLESTA. Portanto, a partir da Seção II o legislador passou para a definição das infrações propriamente ditas, bem como da indicação das penalidades e dos referidos grupos de multa ${ }^{3}$. São do mesmo modo previstas aplicações de medidas de cunho administrativo e trazidas disposições finais.

ANORMAM 07, por sua vez, é uma norma infralegal que aborda a inspeção naval e foi emanada pela própria autoridade marítima, com o objetivo de estabelecer normas administrativas acerca da inspeção naval. O que se nota por meio dessa norma são algumas minúcias e tecnicidades de extrema valia para o deslinde do processo. Exemplificativamente ela indica qual o propósito da inspeção naval; traz questões da execução da inspeção naval; invoca situações excepcionais de restrição ao tráfego aquaviário e de forma taxativa indica quais são as fases do processo administrativo, definindo os prazos para apresentação das peças de defesa, recursos e os destinatários das mesmas.

3 Os grupos A, B, C, D e E constam do anexo II do Decreto e, consoante o grau da infração, a multa pertencerá a um grupo cujo valor da multa será mais elevado. Nota-se aqui uma semelhança com o direito penal, pois há uma espécie de indicação do tipo e a pena a ser aplicada, através da qual o julgador fará a dosimetria da pena conforme o caso concreto. 


\section{$1.3 \mathrm{O}$ processo administrativo e suas fases}

O processo administrativo perante a autoridade marítima segue a regra geral dos processos administrativos. Destacam-se assim: a proteção dos direitos dos administrados, respeito aos princípios da legalidade, finalidade, motivação, razoabilidade, proporcionalidade, moralidade, ampla defesa, contraditório, segurança jurídica, interesse público e eficiência.

Sobre a garantia do contraditório, imposta pela Constituição Federal, Candido Rangel Dinamarco observa que "[...] ela se aplica a todo e qualquer processo - jurisdicional ou não - (art. $5^{\circ}$, inc. LV) e a lei deve instituir meios para a participação dos litigantes no processo e o juiz deve franquear-lhes estes meios." (DINAMARCO, 2013, p. 220).

O início do procedimento ocorre após a constatação da infração, quando então será lavrada a notificação para comparecimento do responsável para prestação de esclarecimentos e obtenção de orientação quanto à prática delitiva e acerca da legislação vigente afeta à segurança da navegação, salvaguarda da vida humana, no mar aberto e em hidrovias interiores. Este ato precede a lavratura do respectivo auto de infração, nos termos do item 0306 da NORMAM 07 e sem a qual nenhuma penalidade poderá ser imposta. Na hipótese de não comparecimento da parte ou se não forem acatados os argumentos apresentados, será instaurado auto de infração. Nesse prisma, Pimenta (2013, p. 27), observa que o procedimento administrativo tem o condão de apurar a infração, determinar os responsáveis e aplicar as penalidades cabíveis.

O administrado terá quinze dias úteis para apresentar defesa no auto de infração, que será julgado pela autoridade marítima competente, 
através de decisão devidamente fundamentada, no prazo de trinta dias corridos (a contar do recebimento da defesa ou caso esta não seja oferecida, após decorrido o prazo para sua apresentação). Em casos de ausência de manifestação, ou em caso de indeferimento da mesma, o auto de infração será julgado procedente e aplicar-se-á uma pena ao infrator.

Desta decisão do julgamento do auto de infração, caberá recurso, que será dirigido à autoridade competente da estrutura da autoridade marítima julgadora, no prazo de cinco dias úteis, contados a partir do dia consecutivo da data do conhecimento da decisão de julgamento do auto. Este recurso será julgado no prazo de trinta dias por meio de decisão, também fundamentada.

Em sendo negado provimento ao recurso e o infrator vindo a se insurgir contra a pena que lhe fora imposta, será admitido recorrer desta decisão, através de recurso em última instância administrativa sem efeito suspensivo, dirigido ao Representante da Autoridade Marítima para a Segurança do Tráfego Aquaviário, no caso da Diretoria de Portos e Costas da Marinha do Brasil, a partir daqui no presente trabalho denominada de "DPC", no prazo de cinco dias úteis, contados da data da notificação da decisão do recurso. A derradeira decisão será emanada no prazo máximo de trinta dias. Após a indicação das fases do processo, cabem algumas observações: no que tange ao recurso, aqui está mais uma garantia posta pelo Estado ao cidadão, afinal não obstante a faculdade de se recorrer para a autoridade máxima da organização militar em que tramitou o processo (Delegado, Agente ou Capitão dos Portos), também é cabível um recurso a ser examinado pelo Almirante Diretor de Portos e Costas em última instância. Acerca dos recursos e dessa possibilidade em articulação com o reexame da matéria, José Carlos Barbosa Moreira aponta que “[...] com o propósito de assegurar, na medida do possível, a justiça das decisões, 
contempla a lei a realização de dois ou mais exames sucessivos, ao passo que, por outro lado, a fim de evitar que se sacrifique a segurança, cuida de limitar o número de revisões possíveis" (MOREIRA, 2008, p. 113). Em que pese o grande processualista ter se referido ao processo civil, este conceito mostra-se totalmente aplicável ao processo administrativo. Cabe ainda destacar em sede recursal, a vedação do reformatio in pejus aplicável ao CPC, que também deve vigorar nos processos dessa natureza.

\section{DIREITO DE DEFESA ENCARADO COMO DIREITO DE PETIÇÃO SOB O PRISMA DO PRINCÍPIO DA INFORMALIDADE}

\subsection{Características principais do instituto do direito de petição}

O direito de petição foi alcançado após muita luta como fruto de grande conquista histórica e, por isso, merece ocupar o espaço que detém no ordenamento jurídico pátrio: consta do artigo $5^{\circ}, \mathrm{XXXIV}$, “a” da Constituição Cidadã. Para Canotilho (2003, p. 512), “o direito de petição é a faculdade reconhecida a indivíduo ou grupo de indivíduos de se dirigir a quaisquer autoridades públicas apresentando petições, representações, reclamações ou queixas destinadas à defesa dos seus direitos [...]". Ou seja, é possível por essa classificação admitir-se petições em sede de impugnação e recurso, ainda que não totalmente claros quanto a seus pedidos, mas se o administrado apresentar qualquer peça reclamando por seus direitos, esta será devidamente tramitada e levada a conhecimento e apreciação da autoridade competente.

Dirley da Cunha Junior entende que este direito afigura-se mais propriamente como uma garantia constitucional de defesa de diretos 
(CUNHA JUNIOR, 2014, p. 565). Por sua vez, Bonifácio (2004, p. 71) na sua obra "Direito de Petição-garantia constitucional", assim define o tema: "[...] a constituição garante ao cidadão-singular ou coletivamente considerado, - um writ em potencial, do qual possa lançar mão contra ações ilegais ou abusivas de poder, praticadas pelo Estado[...].

Esse direito mostra-se um instrumento de extrema valia e garantia ao cidadão que se defrontar com alguma situação de desconforto perante o Estado, seja por conta de uma ação ilegal ou alguma prática de abuso e, com o fito de ver seus direitos restabelecidos, lança mão desta ferramenta que o texto constitucional lhe oferece.

\subsection{O recebimento da peça de defesa como instituto do direito de petição como garantia dos princípios do contraditório e da ampla defesa: respeito ao não formalismo}

A autoridade marítima assegura o direito de defesa do administrado, cumprindo a sua missão. Assim o faz quando do protocolo de peças de defesa, impugnação e até em sede de recursos (os recebe sem que haja a existência de um formalismo exagerado). Inclusive, todas essas peças ainda que carecedoras de técnica apurada e adequada intitulação, muitas vezes são recebidas por respeito ao corolário do direito de petição. São aceitas as petições que demonstrem ter em seu bojo o fito de almejar reverter imputações de atos ou decisões proferidas.

Essa prática da autoridade marítima ocorre em consonância com a eficiência administrativa, boa-fé da administração, instrumentalidade das formas, fungibilidade e principalmente pelo princípio do informalismo e, assim, 
[...] a Administração não poderá ater-se a rigorismos formais ao considerar as manifestações do administrado. [...] se alguém entra com um recurso nominando-o erradamente ou serve-se de um quando o tecnicamente cabível seria outro, ou se propõe a petição ou alegação de prova em formulação não ortodoxa, a Administração não deve mostrar-se rigorosa, mas flexível, para aceitar tais impropriedades (MELLO, 2014, p. 513).

Observa-se que o princípio da informalidade aqui invocado está ligado a uma garantia trazida para os administrados. Como uma peça de defesa pode ser apresentada em um papel de pão por exemplo. Nesse caso, a defesa existe, ela é escrita e fará parte dos autos. Ou seja, o processo não deixa de existir, pelo contrário, apenas há uma relativização no que concerne aos preceitos exigidos de formalidades, afinal, ele recebe autuação, deve ser numerado, seguir um trâmite hierárquico dentro de uma estrutura e ser examinado por uma autoridade competente a quem se outorga poderes para decidir.

Di Pietro (2014, p. 702) sobre essa questão da formalidade (ou do seu esvaziamento) assinala que o "[...] informalismo não significa nesse caso, ausência de forma; o processo administrativo é formal no sentido de que deve ser reduzido a escrito e conter documentado tudo o que ocorre no seu desenvolvimento; é informal no sentido de que não estará sujeito a formas rígidas".

A própria lei do processo administrativo determina como deve ocorrer o seu trâmite, prevendo a "adoção de formas simples, suficientes para propiciar adequado grau de certeza, segurança e respeito aos direitos dos administrados". Para além disso, sempre se buscando 
garantir o contraditório e a ampla defesa, não haverá requisitos especiais para o recebimento dessas peças. Sobre o princípio do contraditório, Dezan $(2015$, p. 157) lembra que em qualquer procedimento público ou privado, o cidadão tem o direito de contrapor-se, antes da decisão final, às imputações que lhe são feitas, podendo peticionar, justificar, requerer e provar posteriormente à acusação e antes da decisão final.

Outro aspecto garantidor dos direitos do infrator reside no fato de que todo o processo tramita sem qualquer cobrança de taxas por parte do Estado ao utente do serviço público. Inclusive para fins recursais, seja em âmbito da própria autoridade julgadora da autoridade marítima, como na última instância recursal, qual seja, a Diretoria de Portos e Costas ("DPC").

Nota-se que em momento algum há uma redução do direito de petição, pelo contrário: o foco é mostrar como a administração pública o valoriza, aceitando peças de defesa sem qualquer formalismo e proporcionando o notório atendimento aos princípios da ampla defesa e do contraditório.

O que se vislumbra mostrar é que mesmo em a autoridade marítima enaltecendo este direito, há casos em que o exercício do direito de defesa é excessivo, não há o que se contestar, não há argumentos novos, a contenda mostra-se temerária, o fato incontroverso e a defesa protelatória. Para estes atos eivados de nítida má-fé processual à luz do CPC, esta norma deve ser aplicada subsidiariamente nos processos administrativos da autoridade marítima, a fim de se inibir essas práticas.

\section{O DEVER FUNDAMENTAL DE COOPERAÇÃO À LUZ DO NOVO CPC}




\subsection{O dever fundamental: conceito do instituto e o dever fundamental de cooperação}

Inicialmente, acerca do conceito de deveres fundamentais compete frisar o estabelecido pelo Grupo de Pesquisa "Estado, Democracia Constitucional e Direitos Fundamentais", do Programa de Pós Graduação Stricto Sensu em Direitos e Garantias Fundamentais da Faculdade de Direito de Vitória - FDV, no curso do segundo semestre de 2014, no sentido de que:

Dever fundamental é uma categoria jurídicoconstitucional, fundada na solidariedade, que impõe condutas proporcionais àqueles submetidos a uma determinada ordem democrática, passíveis ou não de sanção, com a finalidade de assegurar direitos fundamentais a ele correlacionados.

No mesmo sentido, Nabais (2009, p. 64) ao abordar a questão do dever fundamental, expõe que:

[...] os deveres fundamentais constituem uma categoria jurídica constitucional própria colocada ao lado e correlativa da dos direitos fundamentais, uma categoria que como correctivo da liberdade, traduz a mobilização do homem e do cidadão para a realização dos objectivos do bem comum $[\ldots]$.

Um importante dever fundamental é o de cooperação, expressamente previsto no CPC de 2015, como um de seus pilares. Cabe transcrever o artigo $6^{\circ}$ que preceitua que "todos os sujeitos do processo 
devem cooperar entre si para que se obtenha, em tempo razoável, decisão de mérito justa e efetiva" (BRASIL, 2015).

Por cooperação, nos termos do dicionário Michaelis, entende-se: "prestação de auxílio para um fim comum; colaboração, solidariedade" (MICHAELIS, 2017). Com isto em mente, os sujeitos que participam do processo devem lutar por um bem comum, com lealdade, transparência e retidão, a fim de que a causa tenha um deslinde em tempo hábil e com uma duração razoável.

Deve então, a parte deve agir de modo probo, correto e não pautar suas ações em contradições, pois o princípio da cooperação torna devidos os comportamentos necessários à obtenção de um processo leal e cooperativo (DIDDIER JUNIOR, 2015, p. 19).

Espera-se assim do administrado, na qualidade de parte no processo, cooperar tal como todos que do processo façam parte, a fim de que seja obtida uma decisão de mérito justa e razoável, atendendo aos ditames do artigo $6^{\circ}$ do CPC que se aplica de forma subsidiária nos processos administrativos.

\subsection{A boa-fé objetiva}

Intimamente ligada ao dever de cooperação reside a boa-fé. Ambos os institutos guardam próxima relação, pois é uma obrigação da parte agir com lealdade, transparência, retidão, honestidade; e também honrar suas palavras e os compromissos firmados. Não é admitida a conduta protelatória, artifícios ardilosos, argumentos contraditórios que esfacelem o dever fundamental de cooperação.

Alexandre Freitas Câmara bem observa que "não se trata, pois, apenas de se exigir dos sujeitos do processo que atuem com boa- 
fé subjetiva (assim entendida a ausência de má-fé), mas com boa-fé objetiva, comportando-se de maneira como se geralmente espera que tais sujeitos se conduzam" (CÂMARA, 2015, p. 7).

Nessa linha, é fácil constatar que o princípio da boa-fé é a fonte normativa da proibição do exercício inadmissível de posições jurídicas processuais, que podem ser reunidas sob a rubrica do "abuso do direito" processual (desrespeito à boa-fé objetiva). Além disso, o princípio da boafé processual torna ilícitas as condutas processuais animadas pela má-fé (sem boa-fé subjetiva). Ou seja, a boa-fé objetiva processual implica, entre outros efeitos, o dever de o sujeito processual não estar imbuído de má-fé, considerada como fato que compõe o suporte fático de alguns ilícitos processuais (DIDIER JUNIOR, 2015, p. 18).

No âmbito do processo da autoridade marítima que ora se estuda, a própria lei do processo administrativo exige do administrado uma conduta pautada nesta boa-fé objetiva, quando em seu artigo $4^{\circ}$ estabelece que se deva expor os fatos conforme a verdade, proceder com lealdade, urbanidade e boa-fé, não agir de modo temerário.

Logo, se mostra uma exigência tanto do CPC como da Lei especial que regulamenta os processos administrativos, que o particular ao fazer uso do seu direto, o faça de modo solidário sem acarretar insegurança jurídica, riscos e danos tanto ao Estado, quanto a terceiros.

\subsection{Consequências da quebra do dever fundamental de cooperação}

O particular ao inobservar os preceitos éticos trazidos no item anterior e exercer seu direito de defesa com excesso quebra o dever fundamental de cooperação, ocasionando "danos em ricochete", cujas vítimas são os outros administrados e a própria administração pública. 
Evidente que a parte possui o direito de impugnar os atos administrativos, negar as imputações que lhe são feitas pela autoridade marítima, recorrer das sanções que lhe forem aplicadas em todas as instâncias administrativas e sem que lhe seja cobrado qualquer valor a este título. Porém, deve a parte, no delinear de todo o processo, pautar sua conduta pelo respeito à administração pública e aos demais cidadãos que necessitam de uma prestação adequada do serviço público.

Ao passo que um determinado processo que tenha sua duração dilatada por ato nitidamente protelatório e portanto, com deslindes desnecessários (pois como visto, tanto a autoria quanto a materialidade são incontestáveis), trará um dano para outro particular já que o seu processo não será julgado de modo célere. Mas não só, pois a própria administração é lesada por não conseguir realizar sua missão a contento em decorrência de ter de se ocupar com essas causas.

Por conseguinte, isso afeta a gestão administrativa como um todo. Lembra-se que acerca do dever fundamental do Estado de bem prestar serviços públicos, não se trata somente de um dever negativo de abstenção na esfera da autonomia garantida pelos direitos individuais, nem sequer ante o dever de aceitar a participação dos cidadãos na formação da vontade do poder e sim um dever positivo que exige a realização de ações (MARTÍNEZ, 1987, p. 5), tradução nossa) ${ }^{4}$.

Aqui há de se destacar o dever fundamental da parte em cooperar com a administração pública e o dever fundamental do Estado em prestar uma boa administração, através do respeito aos corolários constitucionais da legalidade, impessoalidade, moralidade, publicidade, eficiência,

4 No original: "No estamos ya sólo ante el deber negativo de abstención en la esfera de autonomia garantizada por los derechos individual es, ni siquiera ante el deber de aceptar la participación de los ciudadanos en la formación de la voluntad del poder, sino ante un deber positivo que exige la realización de acciones." 
consagrando ainda o contraditório e a ampla defesa.

Sobre este assunto, Juarez Freitas enfatiza que o utente do serviço público possui um direito fundamental à boa administração pública eficiente e eficaz, proporcional, cumpridora de seus deveres, com transparência, motivação, imparcialidade e respeito à moralidade, à participação social e à plena responsabilidade por suas condutas omissivas e comissivas. A tal direito corresponde o dever de a administração pública observar, nas relações administrativas, a cogência da totalidade dos princípios constitucionais que a regem (FREITAS, 2007, p. 20).

Para ilustrar essa colocação, destaca-se uma transcrição do artigo de Adriano Sant'Ana Pedra e Henrique da Cunha Tavares, no seguinte sentido: "Os deveres se parecem com os direitos fundamentais prestacionais na medida em que, via de regra, exigem posturas positivas dos seus obrigados. Contudo, deles se diferenciam na medida em que os deveres são geralmente veiculados à toda sociedade, não somente ao Estado, posto tratarem-se de deveres fundados na solidariedade e derivados da própria ideia de contrato social. Já os direitos fundamentais prestacionais, a despeito da discussão de sua eficácia horizontal, têm como principal obrigado o Estado" (PEDRA; TAVARES, 2014).

A parte ao deixar de agir em conformidade com a boa-fé objetiva e pautar sua conduta com artifícios ardilosos, deixa de cumprir o dever fundamental de cooperação com a administração pública. Assim, deixa de lado a solidariedade esperada nas condutas dos administrados e acaba por comprometer direitos de outros utentes do serviço público, designadamente o de ter uma causa julgada em tempo razoável.

Outra faceta desse dever fundamental é o da administração pública - sentido horizontal - que deve prestar um bom serviço. O dever fundamental da boa administração confere ao cidadão um direito de 
receber um serviço adequado e eficiente.

No caso ora estudado, porém, as práticas de excesso no exercício destes direitos de defesa, podem acabar fazendo com que a autoridade marítima venha a ficar assoberbada para julgar causas que seriam simples, de autoria e materialidade incontestáveis, com pedido reconhecido implicitamente, podendo eventualmente não conseguir vir a realizar julgamento de outros processos em prazo razoável por culpa de outro.

Portanto, nos casos em que o administrado cometer excessos no seu direito de defesa e, assim, agir de modo temerário sem cumprir seu dever de cooperação, estará ferindo o artigo $6^{\circ}$ do CPC e o $2^{\circ}$ da Lei n. ${ }^{\circ} 9.784$ (BRASIL, 1999b), comprometendo o bom andamento da máquina estatal.

\section{O EXCESSO NO DIREITO DE DEFESA E A POSSIBILIDADE DE APLICAÇÃO DE LITIGÂNCIA DE MÁ-FÉ DO CPC}

As práticas excessivas caracterizam um abuso pelo fato de não estarem em conformidade com o que preconiza o dever fundamental de cooperação. Ao cometer estes excessos, o particular contraria os bons costumes, ignora seu dever de solidariedade e não coopera com a administração pública (no caso com a autoridade marítima). Desta feita, o bom desenvolvimento das atividades estatais resta prejudicado ante a falta de lealdade processual do particular.

Essa atuação danosa aos outros particulares e ao Estado viola o que se tem por boa-fé objetiva e mais, há em muitos casos de ser considerada como prática eivada de má-fé se ocorrer uma das condutas constantes do artigo 80 do CPC. Os casos que assim venham a ser 
caracterizados como má-fé, ultrapassam o mero excesso e passam a se tornar um abuso do direito de recorrer.

O abuso do direito, em palavras simples e objetivas, pressupõe licitude no antecedente e ilicitude no consequente, pois originariamente o agente lança mão de um direito e o exerce com excesso ou com abuso. Por óbvio tais condutas acabam por ferir direitos fundamentais de outros administrados. Acerca dos direitos fundamentais em nossa Constituição, Sarlet (2008, p. 77) assevera a conquista histórica que precedeu toda essa normatização:

[...] De qualquer modo, ficou consagrado o status jurídico diferenciado e reforçado dos direitos fundamentais na Constituição vigente. Esta maior proteção outorgada aos direitos fundamentais manifesta-se, ainda, mediante a inclusão destes no rol das "cláusulas pétreas" (ou "garantias de eternidade") do art. 60, $\S 4^{\circ}$, da CF, impedindo a supressão e erosão dos preceitos relativos aos direitos fundamentais pelo poder Constituinte derivado [...].

A aludida prática do particular que viola o que se tem por lealdade e cooperação, fere a própria estrutura da administração pública, especialmente no que diz respeito à eficiência administrativa.

Ao abordar o princípio da eficiência, Dezan (2015, p. 176) assinala que:

[...] Trata-se do princípio constitucional basilar do agir administrativo (art. 37, caput, CF/88), prescrevendo que a Administração e seus servidores devem não somente cumprir o 
prescrito em lei, mas assim proceder de forma a obter o melhor resultado, o resultado ótimo para o caso concreto $[\ldots]$.

Como narrado, a prática do exercício de defesa e de recurso, eivada de abuso, vai acarretar em má-fé processual. Esta ocorre quando o litigante age em inobservância do dever genérico de boa-fé previsto no artigo $5 .^{\circ}$ do $\mathrm{CPC}$, ou ainda quando deixa de observar qualquer dos deveres processuais específicos enumerados no art. 77 do CPC. Aliás, o rol do artigo 77 e o do artigo 80, ambos do CPC, se complementam, formando um binômio demonstrativo dos deveres das partes e sujeitos processuais, embora o artigo 80 aplique-se exclusivamente aos litigantes (LAMY; RESCHKE, 2015).

Inclusive a condenação por perdas e danos e a fixação da indenização ocorrerão nos próprios autos em que se verificou a litigância de má-fé, podendo se dar até mesmo de ofício (STOCO, 2002, p. 127).

Consoante disposto no seu artigo 15, o CPC pode se aplicar de forma subsidiária em processos administrativos nos casos de silêncio da norma. Em se tratando de processos administrativos da autoridade marítima decorrentes de infrações às normas de segurança do tráfego aquaviário, isto também ocorre. Portanto, em sendo a LESTA, RLESTA e a NORMAM 07 silentes quanto à eventuais ações de administrados eivadas de má-fé, é possível fazer uso deste artigo 15 do CPC, aplicando-o de forma subsidiária e imputando a litigância de má-fé ao particular que cometer o abuso.

Aqui seria a hipótese de excesso do direito de defesa (petiçãorecurso): o representante da autoridade marítima ao julgar o mérito do auto de infração ou de seu recurso, em constatando essa prática, aplicaria 
além da sanção pela infração às normas do tráfego, cumulativamente, outra multa, mas esta referente à prática da litigância de má-fé.

$\mathrm{O}$ artigo 80 do $\mathrm{CPC}$ é taxativo quanto às hipóteses de litigância de má-fé: deduzir pretensão ou defesa contra texto expresso de lei ou fato incontroverso; alterar a verdade dos fatos; usar do processo para conseguir objetivo ilegal; opuser resistência injustificada ao andamento do processo; proceder de modo temerário em qualquer incidente ou ato do processo; provocar incidente manifestamente infundado; interpuser recurso com intuito manifestamente protelatório (BRASIL, 2015).

A título exemplificativo, no que concerne à alteração da verdade dos fatos, traz-se o entendimento de Marinoni, Arenhart e Mitidiero (2015 p. 80), que entendem que esta deva ser "intencional com manifestos propósitos de induzir o órgão jurisdicional em erro" Seria, hipoteticamente, o caso do condutor que ao ser resgatado por agentes da autoridade marítima é visto conduzindo a embarcação e no momento de apresentar sua impugnação ao auto de infração alega que era o passageiro.

Outro ato que fere a lealdade processual, a transparência e a boa-fé objetiva é o venire contra factum proprium. Sobre a vedação imposta a este instituto, Fredie Didier Junior aponta como exemplos dessa prática no processo civil, entre outros, o que preceitua o artigo 1000 do CPC, que veda a possibilidade de interposição de recurso por um litigante que aceitara expressa ou tacitamente uma decisão. $\mathrm{O}$ mesmo autor considera o abuso do direito como conduta ilícita. Assim, emenda que qualquer abuso do direito no processo é proibido pela incidência do princípio da boa-fé processual. Ao final, para citar exemplos, elenca o abuso do direito de defesa e o abuso do direito de recorrer (DIDIER JUNIOR, 2015, p. 17).

A má-fé processual nitidamente afeta a administração, pois ao 
se depararem com processos administrativos que contenham recursos protelatórios, com lides temerárias, alegações infundadas e argumentos contendo alterações da verdade, dificilmente os agentes públicos conseguirão alcançar o melhor resultado do serviço estatal, uma vez que o julgador estará focado em um feito por mais tempo que o devido.

Há que se falar então que por uma conduta violadora dos preceitos da boa-fé objetiva, da ofensa à lealdade processual e assim, uma afronta à solidariedade, deve ser permitida a aplicação subsidiária do CPC para suprir a omissão do legislador no que concerne à litigância de má-fé nestes procedimentos. Neste caso, cabe um paralelo com a fenomenologia, que se apresenta adequada e razoável, pois o fenômeno da má-fé se desvela, não necessitando o julgador ficar apenas restrito ao campo dos conceitos para aplicar o direito tal como ele se mostra. $\mathrm{Ou}$ seja, se a parte recorrer mesmo aceitando expressa ou implicitamente a decisão; deduzir pretensão ou defesa contra texto expresso de lei ou fato incontroverso; usar do processo para conseguir objetivo ilegal; opuser resistência injustificada ao andamento do processo; proceder de modo temerário em qualquer incidente ou ato do processo; provocar incidente manifestamente infundado; interpuser recurso com intuito manifestamente protelatório, não estará cooperando, estará cometendo excesso e agindo com má-fé. Neste sentido, assinala-se que deve ser deixado de lado o formalismo exagerado, na tentativa de demonstrar que o julgador não deve ficar privado de sua liberdade sob o prisma da filosofia fenomenológica, pois o formalismo faz com que o homem acabe por constranger a abertura que lhe é própria e na qual os entes podem aparecer naquilo que são (CUNHA, 2012, p .64).

No mesmo pensamento acerca da possibilidade de aplicação do CPC em processos administrativos, é trazido o conceito de Tupinambá 
(2015, p. 50):

[...] A aplicação supletiva e subsidiária determinada pelo art.15, portanto, importa admitir em prol da efetividade como um fim unitário do direito processual, que a nova regulamentação do novo CPC colmatará lacunas normativas, ontológicas e axiológicas das demais legislações especiais de índole processual, as quais não se acomodarão com interpretações isoladas ou apegadas à eventual reputação de autonomia de seus respectivos ramos de processo[...].

Essa punição pelo abuso do direito (aqui rotulado como excesso no direito de defesa) deve ocorrer para que a parte fique minimamente inibida de reiterar essas condutas. Nessa linha de pensamento, Mauricio Vilela, aponta que ao desatender os preceitos do CPC acerca da matéria, o litigante fere o sistema processual brasileiro e excede os limites de seus direitos postulatórios (VILELA, 2006).

Interpretar a norma com a visada direta no sentido de que o CPC pode vir a ser aplicado de forma subsidiária para inibir a prática do litigante de má-fé retrata pensar em algo maior, no bem comum e na coletividade. Trata-se de uma postura inversa do pensamento "mesquinha" do administrado que para se esquivar de efetuar o pagamento de uma multa por uma infração que ele cometeu e não contestou a materialidade e autoria do fato, age com mecanismos astuciosos causando danos a outros particulares, ferindo o dever de solidariedade e comprometendo o bom funcionamento da administração pública. A aplicação da multa nestes termos teria ainda um viés pedagógico, com o fito de prevenir 
novas práticas atentatórias à administração pública.

\subsection{A aplicação da penalidade por má fé no processo da autoridade marítima em termos concretos}

Como pontuado no decorrer deste estudo, as conquistas de diversos direitos fundamentais advindas de tanta luta e sofrimento do homem (v.g. direito de petição e habeas corpus) devem ser respeitadas nos procedimentos da autoridade marítima e o são, como visto.

Do mesmo modo, o direito ao contraditório e a ampla defesa também merecem respeito por ocasião da aplicação da sanção de multa por má-fé proposta neste artigo. Em termos práticos, se estiverem previstas uma das hipóteses do citado artigo 80 do CPC e a autoridade marítima por ocasião do julgamento do auto de infração entender que para além da condenação pela violação às normas de segurança do tráfego aquaviário, deve aplicar uma sanção por má fé. Cabe ressaltar que no mesmo decisum faria constar essa decisão.

Logo, no mesmo prazo de recurso para guerrear a decisão que penalizou a infração por ofensa à LESTA ou ao RLESTA, o utente do serviço público poderia recorrer contra a decisão que lhe condenou por má fé.

Em termos concretos, a defesa poderia guerrear (i) a condenação pela infração às normas regulamentares da segurança do tráfego aquaviário; (ii) a condenação pela má fé; ou (iii) ambas. Em qualquer das opções isto se daria na mesma peça e no mesmo prazo, em consonância com os postulados da eficiência administrativa e economicidade.

Frise-se, ainda, que caso seja negado provimento ao recurso do administrado em sede de auto de infração, caberá ainda na via 
administrativa, recurso à Diretoria de Portos e Costas, com as mesmas três possibilidades supracitadas e nos mesmos moldes do recurso interposto em sede de auto de infração.

\section{CONCLUSÃO}

Como narrado, nota-se que o ordenamento jurídico pátrio em sua lei maior previu que as Forças Armadas são compostas pela Marinha, pelo Exército e pela Aeronáutica e encontram-se subordinadas ao Ministério da Defesa.

A Marinha, Força sobre a qual versa o presente estudo, exerce a função de autoridade marítima sendo responsável pela fiscalização e segurança do tráfego aquaviário. Dentre as funções da autoridade marítima encontram-se as de criar normas infralegais e promover as ações de inspeção naval. Outrossim, a LESTA, o RLESTA e a NORMAM 07 representam a legislação que abarca o tema em tela.

Por ocasião das práticas de inspeção naval em que são constatadas violações das normas do tráfego aquaviário, o administrado é notificado e inicia-se um processo administrativo para apurar a infração.

O referido processo obedece a todos os preceitos da Lei n. ${ }^{\circ} 9784$, de 1999, quando são facultadas todas as possibilidades de impugnação, revisão, recurso, sempre sob um viés de respeito aos direitos e garantias fundamentais. Ou seja, são atendidas a ampla defesa e o contraditório, por meio de decisões que são proferidas sempre de maneira fundamentada, atuação da administração pautada na moralidade e em total respeito ao artigo 37 da Constituição Cidadã (BRASIL, 1999b).

Ressalta-se que em alguns casos, o administrado ao fazer o uso do seu direito de defesa, seja em sede de impugnação ou em fase recursal, 
o faz sem atender ao formalismo devido, e sem a devida intitulação da peça e do objeto almejado. Todavia, a autoridade marítima em respeito ao princípio do informalismo, da fungibilidade, celeridade e, principalmente em respeito ao direito de petição, recebe a peça e promove o adequado deslinde do feito.

Entretanto, há casos em que o aludido exercício de defesa é procedido com excesso e com abuso: quando o particular age com fins protelatórios; admite implicitamente a decisão, mas oferece um recurso sem qualquer nexo com o objeto da demanda; atua de modo temerário; altera a verdade dos fatos. Em suma, faz um mau uso de um bom direito e acaba por praticar uma das condutas que o artigo 80 do CPC define como má-fé.

Uma atuação revestida destes comportamentos nefastos mostra-se desleal e quebra o dever fundamental de cooperação com a administração pública. A retidão, a transparência, a coerência, o comprometimento e a solidariedade são totalmente esquecidos pelo administrado nessas situações e a boa-fé objetiva ignorada por completo.

Assim, como as aludidas normas que regulamentam o processo administrativo da autoridade marítima são silentes quanto à eventual ação eivada de má-fé e por conseguinte, quanto ao dever de indenização por perdas e danos decorrente desta prática, entende o presente estudo que deve ser aplicado de modo subsidiário o $\mathrm{CPC}$, conforme preceitua seu artigo 15.

Tendo em vista o artigo 79 do CPC prever que responde por perdas e danos aquele que litigar de má-fé como autor, réu ou interveniente, em se constatando a realização de uma das condutas previstas no artigo 80 do CPC (que elenca as ações que são consideradas como má-fé), mostra-se totalmente pertinente uma aplicação de sanção 
ao administrado que assim agir em processo da autoridade marítima.

Verifica-se nessas hipóteses que com essas ações o particular acaba por violar o dever fundamental de cooperação e lesa: (i) o Estado que deverá despender mais tempo que o necessário proferindo decisões em casos incontroversos com autoria e materialidade já definidos; bem como (ii) outros cidadãos que poderão ver seu direito a uma duração razoável ser esvaziado.

As atitudes muitas vezes egoístas da parte em pensar apenas em si, na sua causa, apresentando peças de defesa sem qualquer negação à imputação da violação que lhe foi aplicada (com negativas gerais, argumentos fracos e com o "reconhecimento implícito" da infração), mostram-se uma prática não solidária.

Uma prática de excesso, abusiva do direito de defesa (que como já demonstrado é respeitado no mais alto grau pela autoridade marítima) representa uma quebra do dever de cooperação com a administração pública, atrapalha o pleno cumprimento do dever de boa administração da Marinha e mais, fere direitos fundamentais de outros indivíduos, que verão seus processos com duração não razoável face a essas condutas.

Deve então ser aplicada sanção pecuniária de perdas e danos à parte que agir com má-fé, a fim de reprimir tais condutas temerárias. Mais importante do que o caráter punitivo, este entendimento traz o viés pedagógico, com o fim de desestimular ações danosas. Essas atitudes poderão inibir a disseminação dessas práticas que vem abarrotando a autoridade marítima de recursos inócuos e, assim, será um modo de se frear o improbus litigator de seguir agindo impunemente. 


\section{REFERÊNCIAS}

BONIFÁCIO, Artur Cortez. Direito de petição: garantia constitucional. São Paulo: Método, 2004.

BRASIL. (Constituição). Constituição [da] República Federativa do Brasil. Brasília: Senado Federal, 1988. Disponível em: $<$ http:// www.planalto.gov.br/ccivil_03/constituicao/constituicao.htm>. Acesso em: 26 de junho de 2016.

BRASIL. Decreto n. ${ }^{\circ}$ 2.596, de 18 de maio de 1998. Regulamenta a Lei $\mathrm{n}^{\circ}$ 9.537, de 11 de dezembro de 1997, que dispõe sobre a segurança do tráfego aquaviário em águas sob jurisdição nacional. Disponível em: <http://www.planalto.gov.br/ccivil_03/decreto/D2596. htm>. Acesso em: 26 jun. 2016.

BRASIL. Diretoria de Portos e Costas. Norma da Autoridade Marítima n. ${ }^{\circ}$ 07, de 16 de dezembro de 2003. Disponível em: $<$ https://www.dpc.mar.mil.br/sites/default/files/normam-07.pdf $>$. Acesso em: 26 de junho de 2016.

BRASIL. Lei Complementar n 97, de 9 de junho de 1999. Dispõe sobre as normas gerais para a organização, o preparo e o emprego das Forças Armadas. 1999a. Disponível em: <http://www.planalto.gov.br/ ccivil_03/leis/LCP/Lcp97.htm>. Acesso em: 26 jun. 2017.

BRASIL. Lei n. ${ }^{\circ}$ 9.537, de 11 de dezembro de 1997. Dispõe sobre a segurança do tráfego aquaviário em águas sob jurisdição nacional e dá outras providências. Disponível em: <http://www.planalto.gov.br/ ccivil_03/leis/19537.htm>. Acesso em: 26 jun. 2016.

BRASIL. Lei n. 9.784, de 29 de janeiro 1999. Dispõe sobre a segurança do tráfego aquaviário em águas sob jurisdição nacional e dá 
outras providências. 1999b. Disponível em: <http://www.planalto.gov. br/ccivil_03/leis/19537.htm>. Acesso em: 26 jun. 2016.

BRASIL. Lei n⿳ 13.105, de 16 de março de 2015. Código de Processo Civil. Disponível em: <http:/www.planalto.gov.br/ ccivil_03/_ato2015-2018/2015/lei/113105.htm>. Acesso em: 26 jun. 2016.

CÂMARA, Alexandre Freitas. O novo processo civil brasileiro. São Paulo: Atlas, 2015.

CANOTILHO, José Joaquim Gomes. Direito constitucional e teoria da constituição. 7. ed. Coimbra: Almedina, 2003.

CUNHA JUNIOR, Dirley. Curso de direito constitucional. 8. ed. Bahia: Juspodium, 2014.

CUNHA, Ricarlos Almagro Vitoriano. Segurança jurídica e crise no direito: caminhos para a superação do paradigma formalista. Belo Horizonte: Arraes, 2012.

DEZAN, Sandro Lucio. Fundamentos de direito administrativo disciplinar. 3. ed. Curitiba: Juruá, 2015.

DI PIETRO, Maria Sylvia Zanella. Direito administrativo. 27. ed. São Paulo: Atlas, 2014.

DIDIER JÚNIOR, Fredie. In: CABRAL, Antonio do Passo; CRAMER, Ronaldo (Coord.). Comentários ao novo Código de Processo Civil. Rio de Janeiro: Forense, 2015.

DINAMARCO, Candido Rangel. Instituições de direito processual civil. 7. ed. São Paulo: Malheiros, 2013. 
FABRIZ, Daury Cesar. A eficácia dos direitos sociais após duas décadas da Constituição Brasileira de 1988. Publicações Seriadas do Centro de Estudos Sociais, Coimbra, n. 315, p. 1-13, out. 2008. Disponível em: <http://www.ces.uc.pt/publicacoes/oficina/315/315. pdf $>$. Acesso em: 5 jul. 2016.

FREITAS, Juarez. Discricionariedade administrativa e o direito fundamental à boa administração. São Paulo: Malheiros, 2007.

GILBERTONI, Carla. Teoria e prática do direito marítimo. Rio de Janeiro: Renovar, 2005.

MARINONI, Luiz Guilherme; ARENHART, Sérgio, MITIDIERO, Daniel. Novo código de processo civil comentado. São Paulo: Revista dos Tribunais, 2015a.

MARINONI, Luiz Guilherme; ARENHART, Sérgio; MITIDIERO, Daniel. Novo curso de processo civil: tutela dos direitos mediante procedimento comum. São Paulo: Revista dos Tribunais, 2015b. v. 2.

MELLO, Celso Antônio Bandeira de. Curso de direito administrativo. 31 ed. São Paulo: Malheiros, 2014.

\section{MICHAELIS. Dicionário Brasileiro da Língua Portuguesa.}

Disponível em: <http://michaelis.uol.com.br/moderno-portugues/>. Acesso em: 9 jul. 2017.

MOREIRA, José Carlos Barbosa. O novo processo civil brasileiro (exposição sistemática do procedimento). 27. ed. Rio de Janeiro: Forense, 2008.

NABAIS, José Casalta. O dever fundamental de pagar impostos: contributo para a compreensão constitucional do estado fiscal 
contemporâneo. Coimbra: Almedina, 2009.

NERY JUNIOR, Nelson. Princípios do processo na Constituição

Federal. 11. ed. São Paulo: Revista dos Tribunais. 2012.

PEDRA, Adriano Sant'Ana; TAVARES, Henrique da Cunha. A eficácia dos deveres fundamentais. Revista Derecho y Cambio Social, Perú, v. 37, 2014. Disponível em: <www. derechoycambiosocial.com/revista037/A_EFICACIA_DOS DEVERES_FUNDAMENTAIS.pdf $>$. Acesso em: 12 jun. 2016.

PIMENTA, Matusalém Gonçalves. Processo marítimo: formalidades e tramitação. 2. ed. Barueri: Manole, 2013.

SARLET, Ingo Wolfgang. A eficácia dos direitos fundamentais. 9. ed. Porto Alegre: Livraria do Advogado, 2008.

STOCO, Rui. Abuso de direito e má-fé processual. São Paulo: RT, 2002.

TUPINAMBÁ, Carolina. In: CABRAL, Antonio do Passo; CRAMER, Ronaldo (Coord.). Comentários ao novo Código de Processo Civil. Rio de Janeiro: Forense, 2015.

VILELA, Mauricio. Abuso do direito no novo código civil e o abuso processual. In

MAZZEI, Rodrigo (Coord.). Questões processuais do novo código civil. Barueri: Minha Editora, 2006.

Como citar: GUEDES, João Bernardo Antunes de Azevedo. FABRIZ, Daury Cesar. Dever fundamental de cooperação em processo administrativo da autoridade marítima: possibilidade de aplicação subsidiária do CPC no eu tange à má-fé. Revista do Direito Público, Londrina, v. 12, n. 3, 
p.115-152, dez. 2017. DOI: 10.5433/1980-511X2017v12n3p115. ISSN: 1980-511X.

Recebido em: 30/11/2016

Aprovado em: 08/11/2017 